\title{
Online art class: a study on the cause and effect of plagiarism
}

\author{
Riyan Hidayatullah', Susi Wendhaningsih² \\ Fakultas Keguruan dan Ilmu Pendidikan, Universitas Lampung \\ Correspondence : riyanhidayatullah1987@fkip.unila.ac.id
}

\begin{abstract}
This study discusses the problem of plagiarism in art learning in online classes. The art class was conducted using the Learning Management System (LMS) and attended by 31 Pendidikan Anak Usia Dini (PAUD) students, and arts department. This research method uses a survey derived from two types of data. The first data was obtained from a questionnaire distributed to 211 art students. Factors that determine copy-paste occur because of the tendency to postpone tasks, so they work at the end of time. The following data comes from the discussion assignment report done by the student. Tasks are scanned online using the application. The results of the analysis of plagiarism showed an average of $49.09 \%$, with a word similarity level of $80.77 \%$. Based on online scan reports, the source of plagiarism comes from the university repository. Students use Open Educational Resource (OER) in the form of dictates as material for doing art lecture assignments. In conclusion, students mistakenly understood the use of OER and digital literacy. Digital-based arts learning does not have a significant impact and requires the provision of academic writing.
\end{abstract}

Keywords: Art Learning, LMS, OER, Digital Literacy, Plagiarism

\section{Introduction}

Plagiarism has become the most popular issue among academics of higher education in the past two decades [1]-[3]. The availability of accessing the internet with easily is a factor that encourages students to practice plagiarism [4]. The first plagiarism term noted when Fidentinus recite Martial's poems as if they were his own [5]. Plagiarism is one that determines academic ethics by releasing ideas, revelations, linguistic styles without using appropriate citation styles [6]. Aside from reported, add this category, such as theft of phrase by phrase in small quantities [3], [7]. Another study traces the etymology of the word plagiarism ('literary theft'), from the earlier English word plagiary ('one who wrongfully takes another's words or ideas'), derived from the Latin plagarius ('kidnapper, seducer, plunderer, literary thief'), from plagium (kidnapping) from plaga (snare, net) [3] [8, p. 801]. 
The American Historian Association defines that this is an act of misusing writings from other authors, such as borrowing findings, without attribution, significant research findings, hypotheses, or theories [9]. Plagiarists mentioned in various terms, such as a 'crime' [10], 'theft ideas' [11], 'forgery' [12], 'thought thief' [13], and 'intellectual shoplifter' [14]. Plagiarism is not just related to copypaste but must be seen in a broader context as a matter of cheating [2], [15]-[18]. The root of plagiarism is mental fraudulence, which occurs omission, is repeated, and no one provides education about the importance of appreciating the work and thoughts of other writers. Another perspective thought it was unethical behavior [19], [20]. Everyone is destined to be able to write, but not all of them choose to be honest. Another perspective on plagiarism is an intellectual kinship between writers, not something that opposes intellectual property [21].

Today copy-paste becomes very relentless and widespread because various devices support it. Previous studies have cited opportunities that occur as a result of technological advances. The Copy-paste feature opens up everyone's opportunity to do plagiarism digitally [22]. Ethical violations often occur against intellectual integrity. Self-plagiarism was used by authors to duplicate the scientific work of others [23], [24]. Copy-paste practices in the cyber world are increasingly worrying because they occur in school-age children [25]. Students need to be given knowledge of writing and plagiarism policies, especially for searches through scientific journals [26]. The use of professional plagiarism detection tools is an effective way to prevent this condition from expanding [27]. One is a new method of using statistical properties using common words and latent semantic analysis [28].

The emergence of predatory journals further exacerbated the world of science to suppress plagiarism (García-century, 2019). Cultural factors and educational background also encourage students to commit dishonesty [30] Many students still do not understand about the paraphrasing power in writing, structure, ideas, and the authenticity of the writing style being the key (Suter \& Suter, 2018). In writing, they need guidance from lecturers who have capabilities. The quality of lecturer understanding and awareness of plagiarism is the deciding factor in completing their work [32].

We have conducted although different views on plagiarism, few works two types of case classes (traditional courses and LMS). Corresponding to our knowledge, there have been no investigations focused on plagiarism online art learning practices in Indonesia. Thus, the data collected in this research showed in Indonesian online art classes. The styles and character of Indonesian students turned into an issue that emphasized to uncover the purposes of cheating.

\section{Methods}

This text-matching software was adopted in this research [33], a review of research articles [34]-[36], and surveys [37], [38]. The issue of plagiarism or 
copy-paste syndrome is the basis in reviewing findings of the factors that influence plagiarism, students' perceptions in understanding plagiarism, types of plagiarism, preventative measures, and forms of cases in regular and online classes. The study conducted over two semesters in different classes from faceto-face (FTF) lectures and online.

The data was divided into two, first, taken using a questionnaire for $(\mathrm{N}=$ 211) students from different departments and universities. This data relates to FTF that uses the internet as work material for assignments from Open Educational Resources (OER) [39]-[45]. The other data is taken through Open University (UT) online lecture classes. Samples were taken from online lectures in senior subjects of children's skills. There are two classes and eight sessions each. The response to the students' discussions was taken randomly from each session. Based on the number of students per class of 50 people, only 31 peoples are active in the discussion session. The interval of students age who become respondents ranging from 17-22 years old with different study program backgrounds, such as Dance and Music Education Study programs, Department of Health and Environmental Sanitation, Department of Mechanical Engineering, Early Childhood Education Study Programs, Primary School Teacher Education Study Programs, agribusiness Study Programs, Department of Sports, Counseling Education Study Program, and Islamic Education Study Program. All departments have conducted online art classes

Data analysis utilizes the 'plagiarism checker 6.0.8' application and survey results taken by google form. Student discussion answers are collected based on online class discussions and checked using the application. The presentation of the discussion was made by the lecturer to stimulate students to give answers that came from their ideas. The results of checking using the application are categorized based on the number of students, the percentage of plagiarism, indicated web resources, and the level of plagiarism. In the survey data conducted, the data is displayed in the form of charts to find out what factors encourage students to do plagiarism. Both data are categorized based on the learning mechanism. The first has done by FTF, and students take advantage of open learning sources, such as YouTube, Google, Wikipedia, repositories, and others. Second, students do the learning process in online classes using the Course Management System (CMS) [46], [47] such as Moodle at UT.

\section{Results and discussion}

The first data indicates that the student is copy-pasting. Poll results (given to 211 students) showed that qualifications and time management were highly rated. Fifty-one students thinking of doing the assignment at the deadline, 45 thought this would be more effective and efficient, 45 thought the task given was too difficult. Eighteen students had poor timing, and 19 felt they did not have the 
appropriate literature. Nine people admit that being lazy is the main reason for getting their work done.

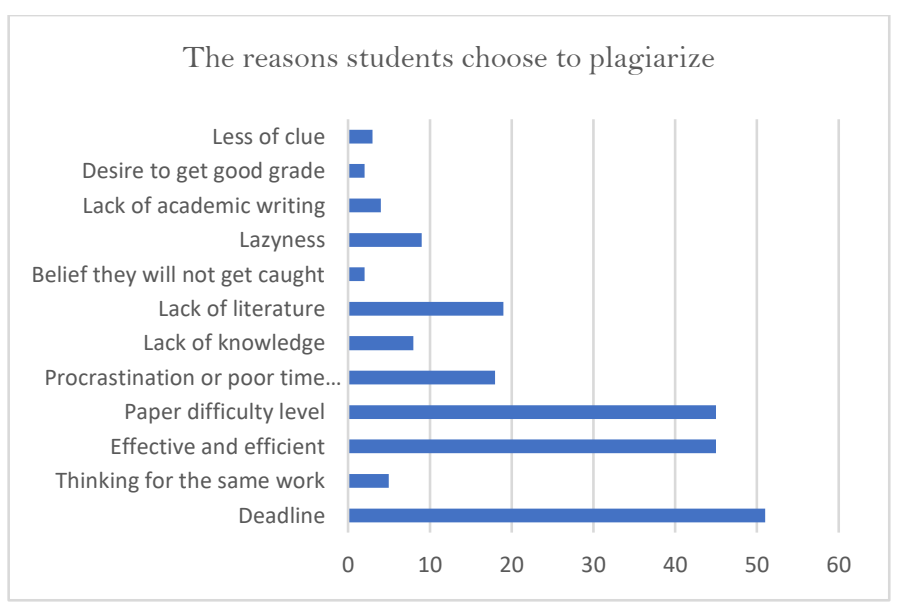

Figure 1 The most frequently stated reasons students choose to plagiarize or cheat

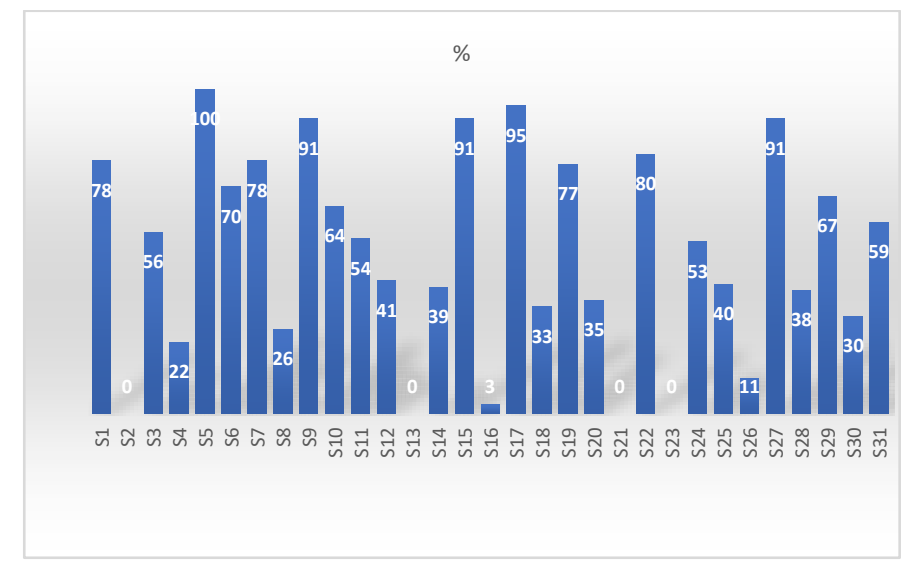

Figure 2 Online plagiarism checking data

The data is the result of plagiarism checks using "online checking". From the 31 students who actively participated in the discussion, there were 18 students who had a "high" level of plagiarism ( $\mathrm{S}_{5}=100$; $\mathrm{S} 17=95$; $\mathrm{S} 9, \mathrm{~S} 15, \mathrm{~S} 27=91 ; \mathrm{S} 22=80$; $\mathrm{S} 1, \mathrm{~S} 7=78 ; \mathrm{S} 19=77 ; \mathrm{S} 6=70 ; \mathrm{S} 29=67 ; \mathrm{S} 10=64 ; \mathrm{S} 31=59 ; \mathrm{S} 3=56 ; \mathrm{S} 11=54 ; \mathrm{S} 24=53$; $\mathrm{S} 12=41 ; \mathrm{S} 25=40$ ), 7 people with a "moderate" level of plagiarism ( $14=39$; $\mathrm{S} 28=38 ; \mathrm{S} 20=35 ; \mathrm{S} 18=33 ; \mathrm{S} 30=30 ; \mathrm{S} 8=26 ; \mathrm{S} 4=22$ ), two people with a "low" plagiarism rate $(\mathrm{S} 26=11 ; \mathrm{S} 16=3)$, and 4 people who do not plagiarism $(\mathrm{S} 2, \mathrm{~S} 13$, $\mathrm{S} 21, \mathrm{~S} 23=0$ ). The highest source of plagiarism comes from official open learning sources (see figure 1). 


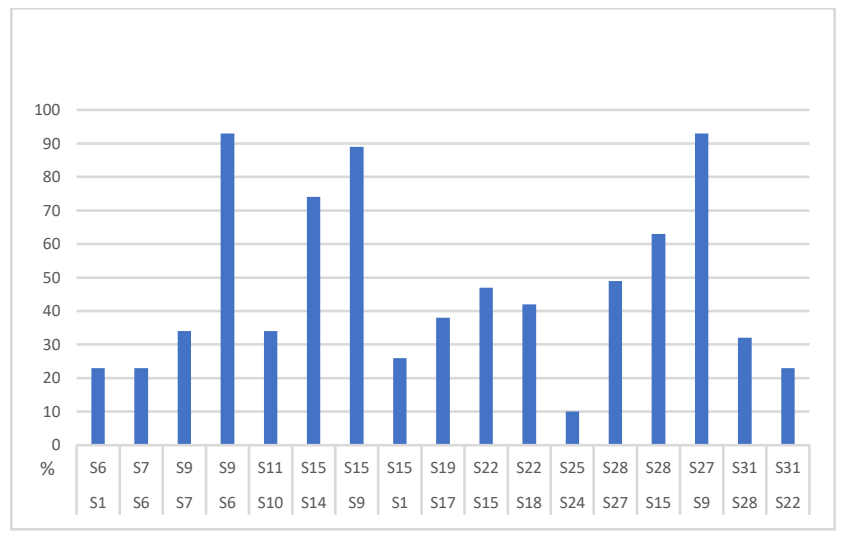

Figure 3 'Side by side' plagiarism data checking

'Side by side' checks are carried out by comparing papers between students. Based on the 31 students who actively discussed, there are similarities in writing at a fairly high level. S9 and S6 = 93\%, S9 and S27 = 93\%, S9 and S15 $=89 \%, \mathrm{~S} 14$ and $\mathrm{S} 15=74 \%$. The writing was found based on the source of the open university digital library (Repository).

Writing a paper is the most challenging part that every student should deal with; besides, art is not in everyone's interest. Thus, completing the paper has several restrictions, for example: (1) giving rise to the desire to fight the lazy; (2) identify references corresponding to the content of the task; (3) competence in writing; (4) systematically create papers and use academic doctrines; (5) the ability to identify and select reliable online library resources; and (6) the ability to utilize big data and the Internet of Things.

The writing art class is theoretically vulnerable to plagiarism, primarily when the activity is carried out online. There is much potential to be able to commit fraud because scholarly people think this has escaped the attention of their teacher or lecturer. They are more brave work in doing copy-paste because they only rely on editing skills and clean up some of the written material defects. Argumentation and reasoning are not tested because the courses have been done asynchronously.

However, in asynchronous online learning can use the debate assignment method [48]. This condition is closed by the digital divide, where knowledge and skills are reduced due to changes in the work and social environment [49], [50]. Technology must be able to function for pedagogical problems that must be developed to be critical [51]-[54] through their creative integration into the social and cultural context [55].

Seeing plagiarism is not just a frightening academic crime but on the side of ignorance of the writer [31].

In addition to writing skills, the ability to read texts, understand the content, and paraphrase are essential things to do [7]. Some students recorded their views in brief sentences. Nevertheless, they point out this work to have a little piracy. The reports are incredibly long and have a magnificent structure; 
however, they have a higher plagiarism tendency. The paraphrases and sentences are perfect.

Open learning sources revealed by plagiarism applications do not appear from google or other search tools, but official textbooks began in the online library on the open university site. The repository is a suitable medium for getting relevant sources. Students think if the questions addressed through the assignment come from texts or open learning sources. The phrase and expression conveyed have similarities with the selected task.

The competence to rephrase, compile, and quotes were the significant obstructions in discussion sessions and working papers. Students get caught on quantity - how many pages they will form regardless of the work subject. Paraphrasing skills are a Long project that takes a long time to comprehend. They do not base their work exercises on these kinds of proficiencies, so working and constructing sentences are terrible for students.

Weblogs are the highest source of plagiarism. The application records up to $90 \%$ similarities in writing on this page. All writings that indicate plagiarism are the same. Therefore, it is not easy to track where the source of the article came from. The qualification of students to classify issues and see open educational sources is surprisingly low. This case generates the work of transcribing in lettering is genuinely minimum. They do not accept the substance of the discourse of the paper as a whole (see figure 2).

Table 1 . the online source with the highest plagiarism level

\begin{tabular}{ll}
\hline No & $\begin{array}{c}\text { Internet webpage with the highest plagiarism } \\
\text { level }\end{array}$ \\
\hline $\mathbf{1}$ & http://repository.ut.ac.id/4712/1/PAUD44 \\
\hline $\mathbf{2}$ & http://luhputulestariani.blogspot.com/20 \\
\hline $\mathbf{3}$ & https://www.nesabamedia.com/pengertian-s \\
\hline
\end{tabular}

\section{Conclusions}

In order to reduce plagiarism, there needs to be new interventions and strategies in managing online classes for students [4]. The key was intervention; it can do by increasing student involvement in active learning and self-efficacy [56]. Active learning needs to be implemented to get meaningful learning activities and require students to think [57]. Active learning in the classroom can make students improve their memory [58]. Thus its method establishes the value of learning on students [59]. Many things happen in the classroom, and teachers focused on how to make students memorized course material, focus on learning outcomes, and somehow do not consider student involvement as well as the ideal classroom according to that view.

Pupils have a pattern of holding their work. This style has repeatedly been a lecturer's obstacle in evaluating work. The timing of the task is the fundamental 
one. Lecturers offer rewards for duty accomplished first, but do not give reprimands for more specific cases about time. Time management by students is seen as common and easy to work with. The perception that the lecturer has differs from the perception of his students about the provision stipulated in the assignment. OER suggests information that can be reached all the times, and students assume it is terribly easy to complete tasks using internet support and numerous resources in it. The Internet brings a wide range of information in 'big data.' Many students could not accept how big data can support the literature reviews. They have not prepared steps and syntax in every class, especially in online classes. Data can be obtained through a massive open online course (MOOC); each student able to access this data from various courses at various top universities [6o, p. 3]. Pedagogy is a way offered to reduce the causes of plagiarism, such as: attitudes, information literacy, moral obligation, and past habits [61].

\section{Acknowledgments}

The authors deeply grateful to All respondent whose comments and suggestions were of inestimable value for my study. We would also like to express my gratitude to my family for their moral support and warm encouragements.

\section{References}

[1] P. J. Larkham and S. Manns, "Plagiarism and its treatment in higher education," Journal of Further and Higher Education, vol. 26, no. 4, pp. 339349, Nov. 2002, doi: 10.1080/0309877022000021748.

[2] D. L. McCabe, L. K. Trevino, and K. D. Butterfield, "Cheating in academic institutions: A decade of research," Ethics \& Behavior, vol. 11, no. 3, pp. 219232, Jul. 2001, doi: 10.1207/S15327019EB1103_2.

[3] C. Park, "In other (People's) words: plagiarism by university studentsliterature and lessons," Assessment \& Evaluation in Higher Education, vol. 28, no. 5, pp. 471-488, 2003, doi: 10.1080/0260293032000120352.

[4] C. Owens and F. A. White, "A 5-year systematic strategy to reduce plagiarism among first-year psychology university students: Long-term plagiarism reduction," Australian Journal of Psychology, vol. 65, no. 1, pp. 1421, Mar. 2013, doi: 10.1111/ajpy.12005.

[5] Martial, Epigrams, vol. 1. London, England: Harvard University Press, 1993.

[6] I. Masic, "Plagiarism in scientific research and publications and how to prevent It," Materia Socio Medica, vol. 26, no. 2, p. 141, 2014, doi: 10.5455/msm.2014.26.141-146. 
[7] N. Das and M. Panjabi, "Plagiarism: Why is it such a big issue for medical writers?," Perspectives in Clinical Research, vol. 2, no. 2, p. 67, 2011, doi: 10.4103/2229-3485.80370.

[8] R. K. Barnhart, Ed., Chambers Dictionary of Etymology, Edinburgh, Chambers. 1988.

[9] F. Fialkoff, “There's no excuse for plagiarism,” Library Journal, vol. 118, no. 17, p. 56, 1993.

[10] A. H. Franke, "Plagiarism," Academe, vol. 79, no. 5, p. 64, 1993.

[11] K. Hopkin, "Scientific plagiarism and the theft of ideas," Science, vol. 261, p. $631,1993$.

[12] N. Groom, "The fine art of making it by faking it," Times Higher Education Supplement, vol. 7 January, pp. 18-19, 2000.

[13] P. Whiteneck, "What to do with a thought thief," Community College Week, vol. 14, no. 24, pp. 4-7, Jul. 2002.

[14] S. Stebelman, "Cybercheating: dishonesty goes digital," American Libraries, vol. 29, no. 8, pp. 48-51, 1998.

[15] D. C. Barnett and Dalton J.C, "Why college students cheat," Journal of College Student Personnel, vol. 22, pp. 545-551, 1981.

[16] V. J. Haines, G. M. Diekhoff, E. E. LaBeff, and R. E. Clark, "College cheating: Immaturity, lack of commitment, and the neutralising attitude," Research in Higher Education, vol. 25, no. 4, pp. 342-354, 1986.

[17] J. S. Leming, "Cheating behavior, subject variables, and components of the internal-external scale under high and low risk conditions," The Journal of Educational Research, vol. 74, no. 2, pp. 83-87, Nov. 1980, doi: 10.1080/00220671.1980.10885288.

[18] W. G. Raffetto, “The cheat," Community and Junior College Journal, vol. 56 , no. 2, pp. 26-27, 1985 .

[19] R. E. Anderson and S. S. Obenshain, "Cheating by students: findings, reflections, and remedies," Academic Medicine, vol. 69, no. 5, pp. 323-332, 1994 .

[20] M. R. Buckley, D. S. Wiese, and M. G. Harvey, "An investigation into the dimensions of unethical behavior," Journal of Education for Business, vol. 73, no. 5, pp. 284-290, May 1998, doi: 10.1080/08832329809601646.

[21] M. Strathern, Kinship, law and the unexpected: Relatives are always a surprise. Cambridge: Cambridge University Press, 2005. 
[22] Y. Kauffman and M. F. Young, "Digital plagiarism: An experimental study of the effect of instructional goals and copy-and-paste affordance," Computers \& Education, vol. 83, pp. 44-56, Apr. 2015, doi: 10.1016/j.compedu.2014.12.016.

[23] I. Blau and Y. Eshet-Alkalai, "The ethical dissonance in digital and nondigital learning environments: Does technology promotes cheating among middle school students?," Computers in Human Behavior, vol. 73, pp. 629-637, Aug. 2017, doi: 10.1016/j.chb.2017.03.074.

[24] R. H. Thurman, F. A. Chervenak, L. B. McCullough, S. Halwani, and D. Farine, "Self-plagiarism: a misnomer," American Journal of Obstetrics and Gynecology, vol. 214, no. 1, pp. 91-93, Jan. 2016, doi: 10.1016/j.ajog.2015.09.004.

[25] C.-M. Chang, Y.-L. Chen, Y. Huang, and C. Chou, "Why do they become potential cyber-plagiarizers? Exploring the alternative thinking of copy-andpaste youth in Taiwan," Computers \& Education, vol. 87, pp. 357-367, Sep. 2015, doi: 10.1016/j.compedu.2015.07.006.

[26] J. Debnath and M. P. Cariappa, "Wishing away Plagiarism in Scientific Publications! Will it work? A situational analysis of Plagiarism policy of journals in PubMed," Medical Journal Armed Forces India, vol. 74, no. 2, pp. 143-147, Apr. 2018, doi: 10.1016/j.mjafi.2017.09.003.

[27] J. Debnath, "Plagiarism: A silent epidemic in scientific writing Reasons, recognition and remedies," Medical Journal Armed Forces India, vol. 72, no. 2, pp. 164-167, Apr. 2016, doi: 10.1016/j.mjafi.2016.03.010.

[28] M. AlSallal, R. Iqbal, V. Palade, S. Amin, and V. Chang, "An integrated approach for intrinsic plagiarism detection," Future Generation Computer Systems, vol. 96, pp. 700-712, Jul. 2019, doi: 10.1016/j.future.2017.11.023.

[29] M. F. Abad-García, "Plagiarism and predatory journals: A threat to scientific integrity," Anales de Pediatría (English Edition), vol. 90, no. 1, p. 57.e1-57.e8, Jan. 2019, doi: 10.1016/j.anpede.2018.11.006.

[30] D. Bikowski and M. Gui, "The influence of culture and educational context on Chinese students' understandings of source use practices and plagiarism," System, vol. 74, pp. 194-205, Jun. 2018, doi: 10.1016/j.system.2018.03.017.

[31] W. N. Suter and P. M. Suter, "Understanding plagiarism," Home Health Care Management \& Practice, vol. 30, no. 4, pp. 151-154, 2018, doi: https://doi.org/10.1177/1084822318779582.

[32] P. Khathayut and C. Walker-Gleaves, "Academic faculty conceptualisation and understanding of plagiarism - a Thai university exploratory study," Journal of Further and Higher Education, vol. o, no. o, pp. 1-15, Jul. 2020, doi: 10.1080/0309877X.2020.1795093. 
[33] D. Keuskamp and R. Sliuzas, "Plagiarism prevention or detection? The contribution of text-matching software to education about academic integrity," Journal of Academic Language \& Learning, vol. 1, no. 1, pp. 91-99, 2007.

[34] A. S. Denney and R. Tewksbury, "How to Write a Literature Review," Journal of Criminal Justice Education, vol. 24, no. 2, pp. 218-234, Jun. 2013, doi: 10.1080/10511253.2012.730617.

[35] A. J. Onwuegbuzie, N. L. Leech, and K. M. T. Collins, "Qualitative Analysis Techniques for the Review of the Literature," The Qualitative Reports, vol. 17, no. 56, pp. 1-28, 2012.

[36] S. B. Qutoshi, "Article review of Randolph (2006) 'a guide to writing the dissertation literature review," VFAST Transactions on Education and Social Sciences, vol. 2, no. 2, pp. 1-4, 2013.

[37] J. A. Fox and P. E. Tracy, Randomized response: A method for sensitive surveys. London: SAGE Publications, Inc., 1986.

[38] G. Hackett, "Survey research methods," The Personnel and Guidance Journal, vol. 59, no. 9, pp. 599-604, May 1981, doi: 10.1002/j.21644918.1981.tboo626.x.

[39] D. E. Atkins, J. S. Brown, and A. L. Hammond, A review of the open educational resources (OER) movement: Achievements, challenges, and new opportunities. United States of America: Creative common, 2007.

[40] N. Butcher, A basic guide to open educational resources (OER). Commonwealth of Learning and UNESCO, 2015.

[41] R. Hidayatullah, "Oer, open access-digital literacy in art education technology based," presented at the Proceeding of International Indonesia Conference on Interdisciplinary Studies: State and Digital Society, Lampung University, Indonesia, Sep. 09, 2018, Accessed: Aug. 28, 2019. [Online]. Available: http://iicis.fisip.unila.ac.id/.

[42] J. Hylén, D. V. Damme, F. Mulder, and S. D’Antoni, "Open educational resources: Analysis of responses to the OECD country questionnaire," OECD Education Working Papers, no. 76, pp. 1-33, 2012, doi: http://dx.doi.org/10.1787/5k99orjhvtlv-en.

[43] J. Pryde, "Open educational resources and the universal library initiative." 2009.

[44] N. Sclater, "Open educational resources: Motivations, logistics and sustainability," in Content management for e-learning, N. Ferrer and J. M. Alonso, Eds. New York: Springer, 2011, pp. 179-193.

[45] L. Yuan, S. MacNeill, and W. Kraan, "Open educational resourcesopportunities and challenges for higher education.," Educational Cybernetics: Reports. Paper 1, pp. 1-34, 2008. 
[46] S. Gibbons, "Library course-management systems: An overview," $A L A$ Library Technology Reports, vol. 41, no. 3, 2005.

[47] Y. Kats, Ed., Learning management system technologies and software solutions for online teaching: Tools and applications. IGI Global, 2010.

[48] E. T. Mitchell, "Using debate in an online asynchronous social policy course," Online Learning, vol. 23, no. 3, pp. 21-33, Sep. 2019, doi: 10.24059/olj.v23i3.2050.

[49] P. Anastasiades, "Lifelong e-learning and digital divide," presented at the Third International Conference on Open and Distance Learning, Patra, Greece: Greek Open University, Nov. 11, 2005.

[50] Norris and Pippa, Digital divide: Civic engagement, information poverty and the Internet worldwide. Cambridge: Cambridge University Press, 2001.

[51] P. Brusilovsky, "Adaptive and intelligent technologies for web-based education," Kunstliche Intelligenz, vol. 4, no. Special Issue on Intelligent Systems and Teleteaching, pp. 19-25, 1999.

[52] P. De Bra, J. Eklund, A. Kobsa, P. Brusilovsky, and W. Hall, "Adaptive hypermedia: Purpose, methods and techniques," presented at the The 1oth ACM Conference on Hypertext and Hypermedia (pp. 199-200), 1999.

[53] S. Kemmis, "Action research and the politics of reflection," in Reflection turning experience into learning, D. Boud, R. Keogh, and D. Walker, Eds. London: RoutledgeFalmer, 1985.

[54] N. Kostoula and Makrakis, Intercultural and education. Athens: Kodikas, 2006.

[55] W. Carr and S. Kemmis, For a critical educational theory: Education, knowledge and action-research. Athens: Kodikas, 2002.

[56] A. R. du Rocher, "Active learning strategies and academic self-efficacy relate to both attentional control and attitudes towards plagiarism," Active Learning in Higher Education, p. 146978741876551, Mar. 2018, doi: 10.1177/1469787418765515.

[57] C. Bonwell and J. Eison, Active learning: Creating excitement in the classroom, ASHEERIC higher education report no.1. George Washington University, Washington, DC., 1991.

[58] I. D. Cherney, "The effects of active learning on students' memories for course content," Active Learning in Higher Education, vol. 9, no. 2, pp. 152171, Jul. 2008, doi: 10.1177/1469787408090841. 
[59] P. L. Machemer and P. Crawford, "Student perceptions of active learning in a large cross-disciplinary classroom," Active Learning in Higher Education, vol. 8, no. 1, pp. 9-30, Mar. 2007, doi: 10.1177/1469787407074008.

[6o] D. Cielen, A. Meysman, and M. Ali, Introducing data science: big data, machine learning, and more, using Python tools. Shelter Island, NY: Manning Publications, 2016.

[61] A. M. Uzun and S. Kilis, "Investigating antecedents of plagiarism using extended theory of planned behavior," Computers \& Education, vol. 144, p. 103700, Jan. 2020, doi: 10.1016/j.compedu.2019.103700. 